\title{
Abuse, disrespect and mistreatment during childbirth care: contribution of the Ribeirão Preto cohorts, Brazil
}

\author{
Abuso, desrespeito e maltrato na assistência ao parto: \\ contribuição das Coortes de Ribeirão Preto, Brasil
}

\author{
Adélia Cristina Vieira de Rezende Dornelas (https://orcid.org/0000-0001-9063-5162) ${ }^{1}$ \\ Lívia dos Santos Rodrigues (https://orcid.org/0000-0003-2933-6125) ${ }^{1}$ \\ Marina Papa Penteado (https://orcid.org/0000-0002-8382-718X) ${ }^{1}$ \\ Rosângela Fernandes Lucena Batista (https://orcid.org/0000-0002-1529-0165) ${ }^{2}$ \\ Heloísa Bettiol (https://orcid.org/0000-0001-8744-4373) ${ }^{3}$ \\ Ricardo de Carvalho Cavalli (https://orcid.org/0000-0001-5010-4914) ${ }^{4}$ \\ Carlos Grandi (https://orcid.org/0000-0001-8336-1183) ${ }^{5}$ \\ Viviane Cunha Cardoso (https://orcid.org/0000-0002-2677-5600) ${ }^{3}$
}

\footnotetext{
${ }^{1}$ Programa de Pós-

Graduação em Saúde da

Criança e do Adolescente,

Faculdade de Medicina

de Ribeirão Preto,

Universidade de São

Paulo. Av. Bandeirantes

3.900, 50 andar. 14049-900

Ribeirão Preto SP Brasil.

adeliacrisvr@bol.com.br

${ }^{2}$ Departamento de Saúde

Pública, Universidade

Federal do Maranhão. São

Luís MA Brasil.

${ }^{3}$ Departamento de

Puericultura e Pediatria,

Faculdade de Medicina de

Ribeirão Preto, Universidade

de São Paulo. Ribeirão Preto

SP Brasil.

${ }^{4}$ Departamento de

Ginecologia e Obstetrícia,

Faculdade de Medicina de

Ribeirão Preto, Universidade

de São Paulo. Ribeirão Preto

SP Brasil.

${ }^{5}$ Research Committee,

Argentine Society of

Pediatrics. Buenos Aires,

Argentina.
}

Resumo O objetivo do estudo foi estimar percepção e ocorrência de situações de abuso, desrespeito e maltrato (ADM) na assistência ao parto de 745 mulheres pertencentes às coortes de nascimentos de Ribeirão Preto. Foram aplicados questionários sigilosos contendo uma pergunta sobre percepção de maltrato na assistência ao parto e outras sobre exposição a situações de ADM. Utilizou-se o teste qui-quadrado para comparar as situações apresentadas entres as mulheres que relataram ou não maltrato. A análise foi realizada por meio do programa Stata 14. Das 745 mulheres avaliadas, $66,2 \%$ foram expostas a alguma situação de ADM e 8,3\% referiram ter percebido ADM. As situações mais frequentes foram: $30,5 \%$ não puderam comer nem beber nada; 27,5\% tiveram sua barriga apertada para ajudar a criança a nascer; e 25,5\% não puderam ficar com acompanhante de sua escolha. Mulheres que afirmaram ter sofrido maltrato apresentaram maiores frequências de respostas positivas a todas situações de ADM quando comparadas com às demais, exceto para os seguintes relatos: "Não me deixaram comer nem beber nada" $(p=0,975)$ e "Fui forçada a ter parto cesáreo contra minha vontade" $(p=0,073)$. Apesar de a maior parte das mulheres pertencentes às coortes de Ribeirão Preto relatarem exposição a situações de ADM durante a assistência ao parto, uma minoria percebeu desrespeito ou maltrato.

Palavras-chave Violência, Parto, Estudos de coorte 


\section{Introduction}

Abuse, disrespect and mistreatment (ADM) of women and girls during childbirth care has been gaining recognition as a problem across the world for more than two decades when the World Health Organization (WHO) declared that mistreating women during childbirth and the associated human rights violations is a "global problem"1. This issue was highlighted in 2015 when the United Nations and regional human rights experts issued a joint statement explicitly asking governments to address "acts of obstetric and institutional violence"2.

In Brazil, the term "obstetric violence" is used to describe these practices of ADM that occur during pregnancy, childbirth, postpartum, and abortion care. Its concepts have been disseminat$\mathrm{ed}^{3-5}$ in an attempt to raise the awareness of both health teams and parturients regarding their rights during delivery. Countries such as Venezuela, Argentina, Bolivia, Panama and Mexico developed legislation around "obstetric violence", a term that encompasses diverse concepts such as disrespectful and abusive treatment of women during pregnancy, childbirth and the postpartum period; unconsented and nonmedically indicated care, and negligence during obstetric emergencies ${ }^{3,4}$.

Nevertheless, it is estimated that $25 \%$ of Brazilian women have suffered some type of violence during their childbirth care. These practices disagree with the movement of humanization of care and scientific evidence in the obstetric field ${ }^{5}$. The reason for the perpetuation of practices associated with obstetric violence has been discussed but its causality is complex and involves the training of health professionals, the structure of healthcare services, the working conditions to which the health team is exposed, and the degree of vulnerability of the attended population, in addition to its relationship with the moral values of the society in which professionals and patients are inserted ${ }^{5}$. Thus, although the concept of humanization of labor and birth is recognized and recommended by entities such as the WHO, Pan American Health Organization (PAHO), Ministry of Health, the Brazilian Unified Health System (SUS), and medical and nursing councils and associations, the delivery process is likely to be subject to violent and inhuman initiatives that disrespect the human and reproductive rights of women during childbirth ${ }^{6}$.

Although many national ${ }^{7-9}$ and international studies ${ }^{10-12}$ have addressed this topic, knowing the situations of disrespect during childbirth care is of great importance since the percentage of women experiencing this event is still high despite current recommendations. Therefore, the present study aimed to estimate and compare the frequency of situations of ADM during childbirth care among participants who perceived mistreatment and who did not of the 1978/79 and 1994 birth cohorts conducted in Ribeirão Preto, São Paulo, Brazil.

\section{Methods}

This was a descriptive study that used data from the Determinants throughout the life cycle of obesity, precursors of chronic diseases, human capital and mental health - RPS Consortium study. The present study included information from the fifth phase of the 1978/79 cohort and the third phase of the 1994 cohort followed up in Ribeirão Preto, São Paulo.

According to IBGE, the population of Ribeirão Preto was 682,302 inhabitants in 2017, with a demographic density of 928.92 inhabitants $/ \mathrm{km}$. There were $98.4 \%$ of households with an adequate sewer system, $92.5 \%$ of urban households on public roads with afforestation, and $64.5 \%$ of urban households on public roads with adequate urbanization ${ }^{13}$. A rich and industrialized region, the Human Development Index (HDI) was 0.855 in 2000 , occupying the sixth position in the state of São Paulo and the $22^{\text {nd }}$ in Brazil ${ }^{14}$.

\section{Population and sample}

The first birth cohort study in Brazil was conducted in 1978/79 and included 6,827 newborn infants from the municipality of Ribeirão Preto ${ }^{15}$. This cohort had several follow-ups ${ }^{16-19}$. In 2016 and 2017, 1,775 individuals ranging in age from 37-39 years were again evaluated. This fifth follow-up phase was dedicated to investigating early determinants of health, such as nutrition and body composition, as well as to assess precursors of complex chronic diseases, mental health, and human capital. In 1994, 2,846 newborn infants in the municipality were evaluated over four consecutive months, corresponding to $1 / 3$ of all births of that year ${ }^{17}$. This cohort was reevaluated during the school period ${ }^{15}$ and the third assessment conducted on 1,041 subjects aged 22-24 years in 2016-2017 occurred simultaneously with the fifth phase of the 1978/79 cohort. Thus, all 
subjects of the two Ribeirão Preto birth cohorts who participated in the fifth (1978/79 cohort) and third (1994 cohort) phases of follow-up were evaluated, totaling 2,816 individuals.

For the present study, it was necessary to select only women who had already been pregnant, so that they could or could not identify situations of ADM during childbirth. A total of 852 women were eligible. Women who did not answer the questions about ADM were excluded and 745 women (632 from the 1978/79 cohort and 113 from the 1994 cohort) were thus evaluated (Figure 1).

\section{Instruments and data collection}

Two questionnaires were used. A general questionnaire that contained socioeconomic and demographic data and life habits of the women was applied by the researcher. The confidential questionnaire was self-administered and addressed issues about the perception and exposure to situations of ADM during labor and delivery. Both surveys were answered using the Research Electronic Data Capture (REDCap) app developed by a multi-institutional consortium that started at Vanderbilt University ${ }^{20}$.

\section{Variables}

The variable "perception of disrespect or mistreatment during labor and delivery" was derived from the initial question: Have you ever felt disrespected or mistreated during labor and delivery of your child? (yes or no). Next, all women responded affirmatively or not to the block corresponding to the exposure to $\mathrm{ADM}$ situations during labor and delivery. The statements are presented in Chart 1.

The following sociodemographic variables and life habits were studied: age (1978/79 cohort with 37-39 years and 1994 cohort with 22-24 years); self-reported skin color (white, non-white); schooling in complete years (up to 4, 5-8, 9-11 and 12 or more); current marital status (single, married/living with a partner, or separated/divorced); head of household (respondent or others), and if religious (yes or no). The socioeconomic class was defined according to the Brazil criterion provided by the Brazilian Association of Research Companies (ABEP): A/B, C, $\mathrm{D} / \mathrm{E}$, with $\mathrm{A} / \mathrm{B}$ corresponding to the highest status $^{21}$.

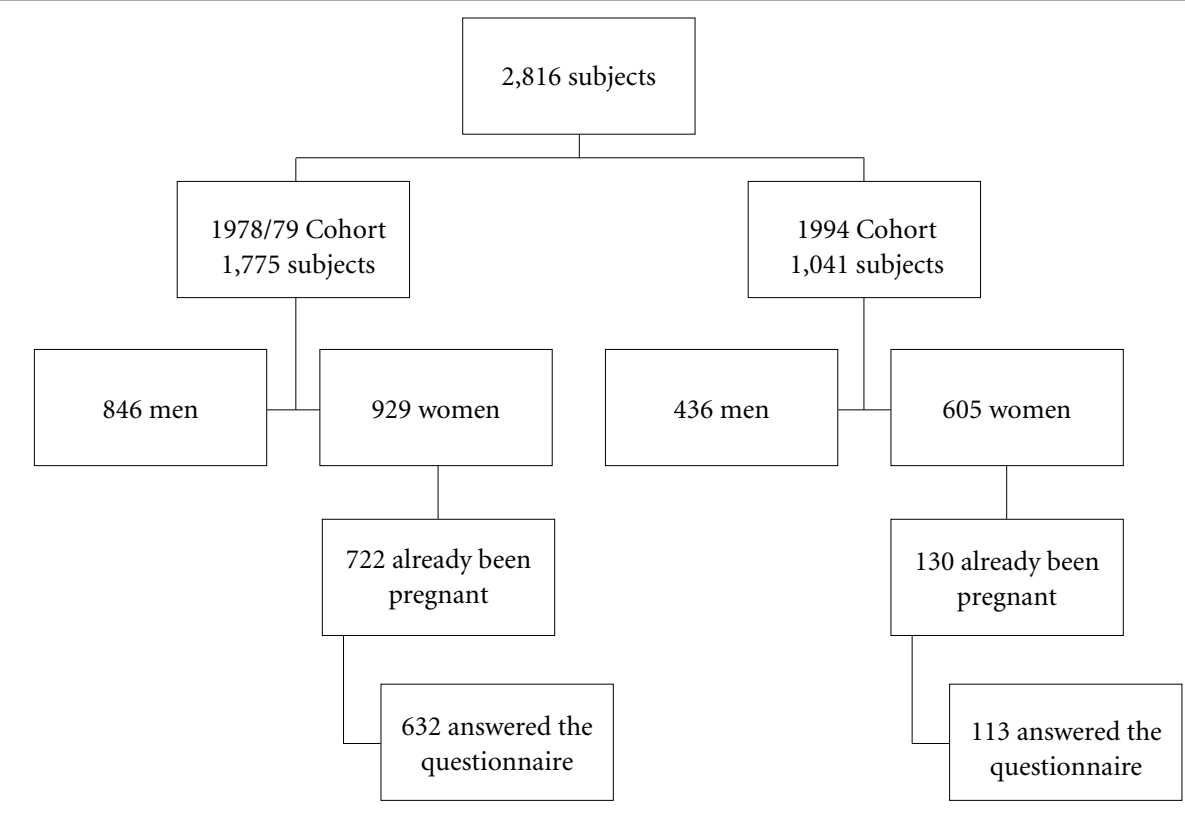

Figure 1. Flowchart of the study population. 
Chart 1. Statements regarding exposure to situations of ADM during childbirth care.

\begin{tabular}{|c|}
\hline ADM during childbirth care \\
\hline I could not stay with a companion of my choice \\
\hline I was not allowed to eat or drink anything \\
\hline They shouted at me \\
\hline They threatened not to take care of me anymore \\
\hline $\begin{array}{l}\text { I was submitted to several vaginal examinations } \\
\text { without being consulted }\end{array}$ \\
\hline $\begin{array}{l}\text { The team caring for me did not explain what was } \\
\text { happening } \\
\text { I was forced to have a vaginal birth against my will }\end{array}$ \\
\hline $\begin{array}{l}\text { I was forced to have a cesarean delivery against my } \\
\text { will }\end{array}$ \\
\hline They squeezed my belly to help the baby be born \\
\hline They did not let me walk when I wanted to \\
\hline $\begin{array}{l}\text { They cut me down there without consulting me/ } \\
\text { against my will }\end{array}$ \\
\hline They cut me down there without anesthesia \\
\hline It took them a while to let me see or pick up the baby \\
\hline $\mathrm{ADM}=$ abuse, disrespect and mistreatment. \\
\hline
\end{tabular}

\section{Statistical analysis}

The prevalence of women who felt mistreated during childbirth and the ADM situations experienced were described. The characteristics of the women according to the perception of disrespect or mistreatment during labor and delivery, as well as exposure to situations of ADM during labor and delivery, were compared by the chisquared test at a level of significance of $5 \%$. The Stata 14.0 software was used for the analyses.

\section{Ethical aspects}

The study was approved by the Research Ethics Committee of the University Hospital of the Ribeirão Preto Medical School, University of São Paulo. All participants received and signed the free informed consent form.

\section{Results}

In the population studied, $62(8.3 \%)$ women felt disrespected or mistreated during labor and delivery, without a difference between the two age groups $(8.5 \%$ of the older cohort and $7.1 \%$ of the younger cohort; $p=0.604)$. There was no differ- ence in socioeconomic or demographic characteristics between women who felt mistreated and those who did not (Table 1).

The 62 participants who reported mistreatment/disrespect were on average 25 years old (SD 5.08) at the time of childbirth when ADM was perceived; the mean gestational age was 37 weeks (SD 1.87) and the mean birth weight of their newborns was $3008 \mathrm{~g}$ (SD 229).

Most deliveries of these 62 women occurred in a public hospital/maternity unit $(77.4 \%)$ and were assisted by a female professional (50\%). In most cases, mistreatment occurred during the birth of the first child (58.1\%), and the type of delivery most frequently associated with memories of disrespect was vaginal delivery (54.8\%). It was reported that $56.4 \%$ of these pregnancies were not planned and labor was induced in only 12 (19.4\%) cases (Table 2).

Approximately $66.2 \%$ of the women experienced at least one situation of $\mathrm{ADM}$ as can be seen in Table 3.

The group of women who reported having suffered ADM during labor or delivery exhibited significantly higher frequencies of positive responses to the different situations of disrespect presented than the remaining women. No difference between groups was only observed for two situations: "I was not allowed to eat or drink anything" and "I was forced to have a cesarean delivery against my will". The situations most frequently cited by women who suffered mistreatment were "The team did not explain what was happening” (59.7\%), "They squeezed my belly to help the baby be born" (41.9\%), and "I could not stay with a companion of my choice" (37.1\%) (Table 4).

There were no differences between the two cohorts, except for the complaint of having been forced to have a vaginal delivery, which was significantly more frequent in the younger cohort $(9.7 \%)$ compared to the older one $(4.6 \% ; p=$ $0.025)$.

\section{Discussion}

The study demonstrated that $66.2 \%$ of the interviewed women reported having suffered at least one of the ADM situations investigated, but only 8.3\% perceived the violence experienced. An important variability was observed in the ADM prevalence of several studies, ranging from 25 to $30 \%{ }^{5}$, while this rate exceeds $80 \%$ in some facilities $^{12,22}$. 
Table 1. Sociodemographic characteristics of women from the 1978/79 and 1994 cohorts according to the perception of maltreatment.

\begin{tabular}{|c|c|c|c|}
\hline \multirow{3}{*}{ Sociodemographic characteristics } & \multicolumn{3}{|c|}{ Perception of maltreatment } \\
\hline & Yes & No & \\
\hline & n (\%) & n (\%) & p \\
\hline Cohort/Age & & & 0.604 \\
\hline 1978/79 (37-39 years) & $54(87.1)$ & $578(84.6)$ & \\
\hline 1994 (22-25 years) & $8(12.9)$ & $105(15.4)$ & \\
\hline Skin color & & & 0.198 \\
\hline White & $52(83.9)$ & $524(76.7)$ & \\
\hline Non-white & $10(16.1)$ & $159(23.3)$ & \\
\hline Years of schooling & & & 0.211 \\
\hline Up to 4 & $1(21.0)$ & $12(12.6)$ & \\
\hline 5 to 8 & $12(40.3)$ & $73(43.4)$ & \\
\hline 9 to 11 & $26(1,6)$ & $343(5.9)$ & \\
\hline 12 or more & $23(37.1)$ & $252(38.1)$ & \\
\hline Socioeconomic class according to $\mathrm{ABEP}^{\star}$ & & & 0.865 \\
\hline $\mathrm{A} / \mathrm{B}$ & $34(58.6)$ & $411(62.1)$ & \\
\hline $\mathrm{C}$ & $22(37.9)$ & $232(35.0)$ & \\
\hline $\mathrm{D} / \mathrm{E}$ & $2(3.5)$ & $19(2.9)$ & \\
\hline Marital status & & & 0.248 \\
\hline Single & $11(17.7)$ & $106(15.5)$ & \\
\hline Married/living with a partner & $41(66.1)$ & $509(74.5)$ & \\
\hline Separated/divorced/widowed & $10(16.2)$ & $68(10.0)$ & \\
\hline Religious & & & 0.124 \\
\hline No & $3(4.8)$ & $76(11.1)$ & \\
\hline Yes & $59(95.2)$ & $607(88.9)$ & \\
\hline Head of household & & & 0.113 \\
\hline Respondent & $29(46.8)$ & $250(36.6)$ & \\
\hline Others & $33(53.2)$ & $433(63.4)$ & \\
\hline Total & $62(100)$ & $683(100)$ & \\
\hline
\end{tabular}

The study "Born in Brazil" based on a survey of labor and delivery involving 23,894 women seen at public, private and mixed maternity units of 266 medium and large facilities located in capitals and towns of 191 municipalities, which was conducted in 2011 and 2012, showed that the procedures related to labor and delivery are increasingly more violent. Good practices during labor were observed in less than $50 \%$ of the women and were less frequent in the North, Northeast and Midwest of the country ${ }^{23}$.

A study conducted in a high-complexity maternity unit in Recife showed that approximately $87 \%$ of patients suffered some type of violence during labor and delivery, considering the use of unnecessary interventions ${ }^{22}$. In a cross-sectional survey carried out in Poland $(\mathrm{n}=8378), 81 \%$ of women experienced violence or abuse from med- ical staff on at least one occasion. The most common abuse was having medical procedures without prior consent ${ }^{12}$. A survey of Brazilian women in public and private facilities showed that $25 \%$ of the respondents were victims of obstetric violence ${ }^{5}$. Another study conducted at a maternity hospital in São Paulo, Brazil, reported a similar percentage, $27.9 \%{ }^{8}$. A similar prevalence of $26.3 \%$ was found in Caracas, with predominantly psychological violence ${ }^{24}$.

The WHO typifies forms of obstetric violence and highlights five categories that operationalize the legal definitions: routine and unnecessary interventions and medicalization; verbal abuse, humiliation or physical aggression; lack of material and inadequate facilities; practices performed by residents and professionals without the woman's permission after providing her comprehensive, 
Table 2. Characteristics of the childbirth care in which mistreatment was perceived.

\begin{tabular}{|c|c|}
\hline $\begin{array}{c}\text { Reproductive and care characteristics } \\
\text { of the participants }\end{array}$ & $\mathbf{n}(\%)$ \\
\hline \multicolumn{2}{|l|}{$\begin{array}{l}\text { Hospital/maternity where the birth took } \\
\text { place }\end{array}$} \\
\hline Private & $10(16.1)$ \\
\hline Public & $48(77.4)$ \\
\hline No information & $4(6.5)$ \\
\hline \multicolumn{2}{|l|}{ Gender of the attending professional } \\
\hline Male & $22(35.5)$ \\
\hline Female & $31(50.0)$ \\
\hline No information & $9(14.5)$ \\
\hline \multicolumn{2}{|l|}{ Type of delivery } \\
\hline Vaginal & $34(54.8)$ \\
\hline Cesarean & $18(29.1)$ \\
\hline No information & $10(16.1)$ \\
\hline \multicolumn{2}{|l|}{ Birth in which mistreatment occurred } \\
\hline First & $36(58.1)$ \\
\hline Second & $16(25.8)$ \\
\hline Third & $4(6.4)$ \\
\hline No information & $6(9.7)$ \\
\hline \multicolumn{2}{|l|}{ Planned pregnancy } \\
\hline No & $35(56.4)$ \\
\hline Yes & $21(33.9)$ \\
\hline No information & $6(9.7)$ \\
\hline \multicolumn{2}{|l|}{ Labor } \\
\hline Induced & $12(19.4)$ \\
\hline Spontaneous & $35(56.4)$ \\
\hline No information & $15(24.2)$ \\
\hline Total & $62(100)$ \\
\hline
\end{tabular}

Source: Authors. truthful and sufficient information; discrimination on cultural, economic, religious, and ethnic ground ${ }^{25}$. Despite the broad dissemination of these guidelines and several studies, there is an evident lack of instruments to measure accurately the occurrence of ADM situations. Generally, the assessments are qualitative and/or quantitative but data collection procedures and interpretation vary widely, a fact that jeopardizes comparisons and limits the knowledge on this problem. One approach used to overcome this difficulty was the development of a quantitative scale that assesses the perspective of final-year midwifery students regarding mistreatments during childbirth ${ }^{26}$.

However, one fact that calls attention is the small number of women who are aware of their obstetric rights. Within this context, Jardim \& Modena $^{27}$ reported that an important issue for the persistence of violence in obstetric care is the lack of knowledge of women about their sexu$\mathrm{al}$ and reproductive rights. According to the authors, the proposal of strategies to prevent and combat this event involves academic training, women's awareness, social mobilization, and the creation of laws and public policies in a joint challenge to guarantee the provision of obstetric carefree of violence and the respect of sexual and reproductive rights.

According to Schraiber et al. ${ }^{28}$, it should be considered that the difficulty in expressing experienced violence can be a communication problem since the meaning of the word violence varies a lot. In his study, 322 women aged 15 to 49 were

Table 3. Exposure to situations of ADM during childbirth care.

\begin{tabular}{lr}
\multicolumn{1}{c}{ ADM during childbirth care } & n (\%) \\
\hline I was not allowed to eat or drink & $227(30.5)$ \\
They squeezed my belly to help the baby be born & $205(27.5)$ \\
I could not stay with a companion of my choice & $190(25.5)$ \\
The team did not explain what was happening & $115(15.4)$ \\
It took them a while to let me see or pick up the baby & $96(12.9)$ \\
They cut me down there without my permission & $72(9.7)$ \\
They did not let me walk when I wanted to & $58(7.8)$ \\
I was submitted to several vaginal examinations without being consulted & $47(6.3)$ \\
They cut me down there without anesthesia & $47(6.3)$ \\
I was forced to have a vaginal birth against my will & $40(5.4)$ \\
They shouted at me & $37(5)$ \\
They threatened not to take care of me anymore & $15(2)$ \\
I was forced to have a cesarean delivery against my will & $14(1.9)$ \\
\hline
\end{tabular}

$\mathrm{ADM}=$ abuse, disrespect and mistreatment. 
Table 4. Exposure to ADM situations during childbirth care according to the perception of mistreatment.

\begin{tabular}{lrrr}
\hline & \multicolumn{2}{c}{ Perception of mistreatment } \\
\cline { 2 - 3 } & \multicolumn{1}{c}{ ADM during childbirth care } & Yes & p \\
\cline { 2 - 3 } & $\mathbf{n}(\%)$ & $\mathbf{n}(\%)$ & \\
\hline I was not allowed to eat or drink & $208(30.5)$ & $19(30.6)$ & 0.975 \\
They squeezed my belly to help the baby be born & $179(26.2)$ & $26(41.9)$ & $\mathbf{0 . 0 0 8}$ \\
I could not stay with a companion of my choice & $167(24.4)$ & $23(37.1)$ & $\mathbf{0 . 0 2 9}$ \\
The team did not explain what was happening & $78(11.4)$ & $37(59.7)$ & $<\mathbf{0 . 0 0 1}$ \\
It took them a while to let me see or pick up the baby & $76(11.1)$ & $20(32.7)$ & $<\mathbf{0 . 0 0 1}$ \\
They cut me down there without my permission & $55(8.0)$ & $17(27.4)$ & $<\mathbf{0 . 0 0 1}$ \\
They did not let me walk when I wanted to & $48(7.0)$ & $10(16.1)$ & $\mathbf{0 . 0 1 0}$ \\
I was submitted to several vaginal examinations without being consulted & $29(4.3)$ & $18(29.0)$ & $<\mathbf{0 . 0 0 1}$ \\
They cut me down there without anesthesia & $39(5.7)$ & $8(12.9)$ & $\mathbf{0 . 0 2 6}$ \\
I was forced to have a vaginal birth against my will & $25(3.7)$ & $15(24.2)$ & $<\mathbf{0 . 0 0 1}$ \\
They shouted at me & $17(2.5)$ & $20(32.3)$ & $<\mathbf{0 . 0 0 1}$ \\
They threatened not to take care of me anymore & $8(1.2)$ & $7(11.3)$ & $<\mathbf{0 . 0 0 1}$ \\
I was forced to have a cesarean delivery against my will & $11(1.6)$ & $3(4.8)$ & 0.073 \\
\hline ADM
\end{tabular}

$\mathrm{ADM}=$ abuse, disrespect, and mistreatment.

Source: Authors.

interviewed; $69.6 \%$ referred to some physical, psychological or sexual aggression but $63.4 \%$ did not consider that they had undergone violence in life. It is named invisibility of violence.

Although studies indicate that women with a lower educational level ${ }^{22}$ and socioeconomically disadvantaged ${ }^{23,27}$ would be the most exposed to situations of ADM, the present study was unable to identify sociodemographic characteristics that could discriminate women who perceived the violence experienced. Most participants in this group had an unplanned pregnancy, were attended in a public maternity hospital by a female professional, and the complaint occurred in the first birth, which was generally spontaneous and vaginal. Another important information was the mean maternal age ( 25 years), the mean newborn weight $(3,007.9 \mathrm{~kg})$, and the mean gestational age (37 weeks) at childbirth, which do not suggest any special characteristics that would promote abnormal conditions of labor or delivery.

The literature has discussed the unnecessary and/or harmful practices of the current interventionist care model. Studies have shown that being attended by a doctor increases the risk (RR 1.56; 1.38-1.76) of exposure to ADM situation ${ }^{22}$. In the present study, we did not collect data regarding the professional who provided childbirth care (doctor, nurse, obstetrician), nor regarding the medical conditions of the respondents during hospitalization. Women who perceived maltreat- ment were treated in $50 \%$ of cases by a female professional.

The most frequent situations of ADM reported by this population were the impossibility of eating/drinking during labor, having the belly squeezed to help with delivery and the impossibility of choosing a companion. When only women who perceived ADM situations were evaluated, the main complaint was the lack of explanations provided by the medical team, while the other group continued to report the lack of permission to eat or drink during labor. Regardless of this difference between groups, it was observed that the complaints raised are the same as those reported in other surveys ${ }^{8,22,23}$.

Allowing the woman to have a companion of her free choice during labor, delivery and postpartum is considered a beneficial conduct that should be encouraged and is supported by scientific evidence. Women who receive continuous support during labor, compared to those who do not, are more likely to not require cesarean section and to have a vaginal delivery without the use of analgesia, in addition to shorter labor and less dissatisfaction with the experience of the birth process ${ }^{29}$.

In a previous study, $29.5 \%$ of women were submitted to the Kristeller maneuver during vaginal birth and cesarean sections performed after attempts of vaginal delivery. This maneuver was developed without any scientific basis and is 
frequently performed by health professionals in conjunction with other inappropriate interventions to accelerate labor dynamics. In addition to the discomfort caused by pain, this maneuver can have serious consequences such as trauma to the abdominal viscera and uterus and detachment of the placenta ${ }^{30}$.

Despite the recommendation that women must maintain oral water and food intake in lowrisk deliveries ${ }^{1}$, only $25.2 \%$ in average of Brazilian women were able to eat during parturition ${ }^{23}$. Biscegli et al. ${ }^{8}$ observed that fasting was maintained for $8.5 \%$ of parturients.

The design of the present study did not allow to evaluate good practices in routine obstetric care, only to discuss situations of ADN that are still a reality in maternity facilities of Brazil. No information on the reproductive health at delivery were recorded, and the possibility of reminder bias exists since the interval between the event and the assessment varied widely and was uncontrolled.

\section{Collaborations}

ACVR Dornelas designed the study, collected and analyzed data, and wrote the paper; LS Rodrigues contributed to data analysis and critical review of the paper; MP Penteado contributed to data analysis and critical review of the paper; RFL Batista carried out a critical review of the study; $\mathrm{H}$ Bettiol carried out a critical review of the study; RC Cavalli carried out a critical review of the study; C Grandi designed the study, collected and analyzed data, and wrote the paper and VC Cardoso designed the study, collected and analyzed data, and wrote the paper. All authors approved the final version to be published.
Comparison of the group of women who perceived ADM and those who did not reiterate the subjectivity of the information recorded, since not recognizing these situations does not mean that the care provided was not disrespectful. This fact confirms the importance of discussing this topic since childbirth is part of the list of the most significant human experiences for those involved.

In conclusion, the high rate of women exposed to situations of ADM during childbirth care among participants in the two Ribeirão Preto follow-up cohorts is still a matter of concern, as is the poor recognition of this fact. The training of health providers during undergraduate, specialization and continuing education, interventions aimed at informing and strengthening the autonomy of women and families, and visualization and accountability have been indicated as the best strategies ${ }^{31}$.

Future research is needed to evaluate the best methodology and to assess the determinants and consequences of mistreatment during childbirth from various perspectives. 


\section{Acknowledgments}

We thank the women who generously contributed information to this work. The study was supported by the Science of Technology Department, Brazilian Ministry of Health; Fundação de Apoio ao Ensino, Pesquisa e Assistência, Hospital das Clínicas, Faculdade de Medicina de Ribeirão Preto, Universidade de São Paulo (FAEPA), and Coordenação de Aperfeiçoamento de Pessoal de Nível Superior (CAPES).

\section{References}

1. Organização Mundial de Saúde (OMS). Maternidade Segura. Assistência ao parto normal: um guia prático. Genebra: OMS; 2009.

2. Murray de Lopez J. When the scars begin to heal: narratives of obstetric violence in Chiapas, Mexico. Int $J$ Heal Gov 2018; 23(1):60-69.

3. Gherardi N. Otras formas de violencia contra las mujeres que reconocer, nombrar y visibilizar. Serie Asuntos de género 141. Santiago: Cepal; 2016.

4. Asamblea Nacional de la República Bolivariana de Venezuela. Ley Orgánica sobre el derecho de las mujeres a una vida libre de violencia, Ley $\mathrm{n}^{\circ} 38.668$, del 23 de abril de 2007. 2007.

5. Fundação Perseu Abramo. Mulheres brasileiras e gênero nos espaços públicos e privados. São Paulo; 2011.

6. Rodrigues DP, Alves VH, Vieira RS, Morett C, Leão R, De Paula E, Pimentel MM. Obstetric Violence in the Context of Labor and Childbirth. J Nurs UFPE line 2018; 12(1):236-246

7. Diniz SG, Salgado HO, Andrezzo HFA, Carvalho PGC, Carvalho PCA, Aguiar CA, Niy DY. Abuse and disrespect in childbirth care as a public health issue in Brazil: origins, definitions, impacts on maternal health, and proposals for its prevention. J Hum Growth Dev 2015; 25(3):377-382.

8. Biscegli TS, Grio JM, Melles LC, Ribeiro SRMI, Gonsaga RAT. Violência obstétrica: perfil assistencial de uma maternidade escola do interior do estado de São Paulo. Cuid Enferm 2015; 9(1):18-25.

9. Rodrigues FAC, Lira SVL, Magalhães PH, Freitas ALV, Mitros VMS, Almeida PC. Violência obstétrica no processo de parturição em maternidades vinculadas à Rede Cegonha. Reprod e Clim 2017; 32(2):78-84.

10. De Lopez JM. When the scars begin to heal: narratives of obstetric violence in Chiapas, Mexico. Int J Heal Gov 2018; 23(1):60-69.

11. D’Oliveira AFPL, Grilo Diniz S, Blima Schraiber L. Violence against women in health-care institutions: an emerging problem. Lancet 2002; 359(9318):16811685.

12. Baranowska B, Doroszewska A, Kubicka-Kraszyńska U, Pietrusiewicz J, Adamska-Sala I, Kajdy A, Sys D, Tataj-Puzyna U, Bączek G, Crowther S. Is there respectful maternity care in Poland? Women's views about care during labor and birth. BMC Pregnancy Childbirth $2019 ; 19(1): 1-9$.

13. IBGE. IBGE Cidades [Internet]. [cited 2020 Jun 5]. Available from: https://cidades.ibge.gov.br/brasil/sp/ ribeirao-preto/panorama

14. DATASUS. Cadernos de Informações em Saúde - São Paulo [Internet]. [cited 2020 Jun 5]. Available from: http://tabnet.datasus.gov.br/tabdata/cadernos/cadernosmap.htm.2019

15. Cardoso VC, Simões VMF, Barbieri MA, Silva AAM, Bettiol H, Alves MTSSB, Goldani MZ. Profile of three Brazilian birth cohort studies in Ribeirão Preto, SP and São Luís, MA. Braz J Med Biol Res 2007; 40:11651176.

16. Tome FS, Cardoso VC, Barbieri MA, Silva AAM, Simoes VMF, Garcia CA, Bettiol H. Are birth weight and maternal smoking during pregnancy associated with malnutrition and excess weight among school age children? Braz J Med Biol Res 2007; 40(9):1221-1230. 
17. Bettiol H, Sabbag Filho D, Haeffner LSB, Barbieri MA, Silva AAM, Portela A, Silveira P, Goldani MZ. Do intrauterine growth restriction and overweight at primary school age increase the risk of elevated body mass index in young adults? Braz J Med Biol Res 2007; 40(9):1237-1243.

18. Barbieri MA, Bettiol H, Silva AAM, Cardoso VC, Simoes VM, Gutierrez MR, Castro JA, Vianna ES, Foss MC, Santos JE, Queiroz RG. Health in early adulthood: the contribution of the 1978/79 Ribeirao Preto birth cohort. Braz J Med Biol Res 2006; 39(8):10411055.

19. Bettiol H, Barbieri MA, Gomes UA, Andrea M, Goldani MZ, Ribeiro ERO. Saúde perinatal: metodologia e características da população estudada . Rev Saude Publica 1998; 32(1):18-28.

20. Patridge EF, Bardyn TP. Research electronic data capture (REDCap). J Med Libr Assoc 2018; 106(1):142144.

21. Associação brasileira de empresas de pesquisa (ABEP). Critério Padrão de Classificação Econômica Brasil [Internet]. 2020. [cited 2020 Jun 5]. Available from: http://www.abep.org/criterio-brasil

22. Andrade PON, Silva JQP, Diniz CMM, Caminha MFC. Fatores associados à violência obstétrica na assistência ao parto vaginal em uma maternidade de alta complexidade em Recife, Pernambuco. Rev Bras Saude Matern Infant 2016; 16(1):29-37.

23. Leal MC, Pereira APE, Domingues RMSM, Filha MMT, Dias MAB, Nakamura-Pereira M, Bastos MH, Gama SGN. Intervenções obstétricas durante o trabalho de parto e parto em mulheres Brasileiras de risco habitual. Cad Saude Publica 2014; 30(Suppl. 1):1-16.

24. Pereira CJ, Domínguez AL, Merlo JT. Violencia obstétrica desde la perspectiva de la paciente. Rev Obstet Ginecol Venez 2015; 75(2):81-90.
25. Castrillo B. Dime quién lo define y te diré si es violento. Reflexiones sobre la violencia obstétrica. Sex Salud $y$ Soc 2016; (24):43-68.

26. Bakker R, Sheferaw ED, Stekelenburg J, Yigzaw T, Kroon MLA. Development and use of a scale to assess gender differences in appraisal of mistreatment during childbirth among Ethiopian midwifery students. PLoS One 2020; 15(1):e0227958 .

27. Jardim DMB, Modena CM. Obstetric violence in the daily routine of care and its characteristics. Rev Lat Am Enfermagem 2018; 26:e3069.

28. Schraiber L, d'Oliveira AF, Hanada H, Figueredo W, Couto M, Kiss L, Durand J, Pinho A. Violência vivida: a dor que não tem nome. Interface (Botucatu) 2003; 7(12):41-54.

29. Oliveira TR, Costa REOL, Monte NL, Veras JMMF, Sá MIMR. Percepção de mulheres sobre violência obstétrica. Rev enferm UFPE 2017; 11(1):40-46.

30. Lima KD de. Raça e violência obstétrica no Brasil [monografica]. Recife: Centro de Pesquisas Aggeu Magalhães; 2016.

Article submitted 16/09/2020

Approved 09/02/2021

Final version submitted 11/02/2021

Chief editors: Romeu Gomes, Antônio Augusto Moura da Silva 